\title{
A Study on the Issue Analysis for the Application of BIM Technology to Civil Engineering in Korea
}

\author{
Ki Beom Ju, Myoung Bae Seo \\ ICT Convergence and Integration Research Division, Korea Institute of Construction Technology(KICT), \\ Ilsan, Rep. of Korea \\ Email: kbju@kict.re.kr, smb@kict.re.kr
}

Received 2012

\begin{abstract}
As conducted in the field of construction, the utilization of BIM (Building Information Modeling) is becoming a hot issue for many public work projects. Also, its market seems to be expanded as BIM is applied in procurement constructions. In this study, it examined the current state of BIM application that is being utilized in Civil Engineering nowadays for the BIM technology application while analyzing the issues raised regarding its application. The analyzed issues - Break off of BIM data in each construction stage, lack of cooperative system, insufficient standard library and guideline, etc. - were classified in terms of process infrastructure and system, and each measure for improvement was derived. It is advised to establish the method of strategic approach and detailed action plan for the execution of the improvement measures.
\end{abstract}

Keywords: BIM; Standard; BIM Technology; Issue Analysis

\section{Introduction}

Currently, in the same way as construction field, interests regarding the application of BIM (Building Information Modeling) in Korean civil engineering projects have been increasing and it has been recognized as the means of competitiveness as technological adoption is being accelerated.

According to the presentation given by Korean Procurement, from the year 2012, turnkey design competition construction of over 50 billion won have to apply BIM as an obligation.

If this trend leads on, it is considered that the application of BIM in civil engineering field will take place in the near future, but in the industry, preparations have not been made sufficiently and various problems recognized by practitioners still exists.

In this research, reports were conducted by basing on the BIM market structure of Korean civil engineering field, and civil engineering companies that are using BIM or are in plans of using BIM in the near future have been reported based on their awareness, level, and problems regarding BIM, and improvement that can be made to effectively apply BIM onto the civil engineering field has been briefly suggested.

For the research method, the BIM application status of Korean civil engineering has been investigated to analyze the problems. Secondly, problems are investigated through literature review. Thirdly, based on the survey regarding interests of BIM that was conducted by the Korean Construction Technology Research Center, similar surveys were re-surveyed in order to examine the changes over the past 2 years as well as recognizing changes in problems of BIM technology. Lastly, analyzed and examined problems are classified in order as the research was progressed.

\section{BIM Application Status in Public Organizations Of South Korea}

Since civil facilities are facilities maintained by the nation, public organizations become in charge of orders and maintenance management. Amongst the ordering information of the public organization, when 6 representing cases (refer to Table 1) are observed, it is displayed that BIM technology is being applied in different civil facilities such as bridges, rivers, dams, and railways. Most are applied in the designing stage, and it has been reported that the major usages are for process management and stimulation and advertisement.

Table 1.

Ordering STatus of Public Organizations in South Korea.

\begin{tabular}{|c|c|c|}
\hline & Main Content & Related Business \\
\hline $\begin{array}{l}\text { Ministry of Land, } \\
\text { Transport and } \\
\text { Maritime Affairs }\end{array}$ & $\begin{array}{l}\text { Review of the } \\
\text { appropriateness of the } \\
\text { accomplishment such as } \\
\text { drawings and quantities }\end{array}$ & $\begin{array}{l}\text { Multifunctional Adminisrative } \\
\text { City Four Bridges in Geum } \\
\text { River }\end{array}$ \\
\hline $\begin{array}{l}\text { The Korea Land \& } \\
\text { Housing } \\
\text { Corporation (LH) }\end{array}$ & $\begin{array}{l}\text { 3D Process } \\
\text { Management (4D) and } \\
\text { Advertisement }\end{array}$ & $\begin{array}{l}\text { Barrage Structural Reformation } \\
\text { Proejct of Young San River 3in } \\
\text { process) Water Proof } \\
\text { Construction Project in } \\
\text { Saemangeum (7in process) }\end{array}$ \\
\hline $\begin{array}{l}\text { Korea Rural } \\
\text { Community } \\
\text { Corporation (KRC) }\end{array}$ & $\begin{array}{l}\text { 3D Process } \\
\text { Management (4D) and } \\
\text { Advertisement }\end{array}$ & $\begin{array}{l}\text { Restoration of Nakdong } \\
\text { River(4 in process ) Young Ju } \\
\text { Dam Construction of Industrial } \\
\text { Water Supply in DaSan Coastal } \\
\text { Industral Area }\end{array}$ \\
\hline $\begin{array}{l}\text { Korea Water } \\
\text { Resources } \\
\text { Corporation }\end{array}$ & 3D Process Stimulation & $\begin{array}{l}\text { Ho Nam High Speed Railways } \\
\text { Capital High Speed Railways }\end{array}$ \\
\hline $\begin{array}{l}\text { Korea Rail } \\
\text { Network Authority }\end{array}$ & $\begin{array}{l}\text { 3D Mileage Stimulation } \\
\text { "Design Utilization of } \\
\text { 3D Stimulation" }\end{array}$ & $\begin{array}{l}\text { Outer Circular Highway in } \\
\text { Busan }\end{array}$ \\
\hline $\begin{array}{l}\text { Korea Expressway } \\
\text { Corporation }\end{array}$ & $\begin{array}{l}\text { 3D Process } \\
\mathrm{y}_{\text {Management (4D) and }} \\
\text { Advertisement }\end{array}$ & $\begin{array}{l}\text { Restoration of Nakdong River } \\
\text { ( } 4 \text { in process) }\end{array}$ \\
\hline
\end{tabular}


In case of private construction companies, in order to certify the effects of BIM in bridges, subways, and harbors, it has been reported that it is being introduced in form of experiments.

The problems in BIM expressed in the application of public organization are based on the fact that most important usage are implemented in form of process application for advertisement instead of actual process management. This makes re-cycling insufficient, and was analyzed as a problem.

\section{Prblems and Restraits in Introduction Seen Through Resources}

When problems from the thesis related to BIM presented in Korea are extracted, Son Bo Shik and the rest 1 (2008) stated that changes in the process, software selection, systematization of information, education, list of required condition, and parts about performance measurement are in the lacking state and are identified as important improvements that need to be made in order for BIM application to take place. Seo Jong Chul and the rest (2009) pointed out the problems related to the introduction and application of BIM as related to education, secure of library, compatible data, and data ownership. They also explained that provision of standard development of equipments and institutional guidelines is urgent. Kim Hwa Sung (2010) pointed out the problems related to application of BIM during the construction stage as the lack of reliability in the design model, performance improvement on the program, delay caused by design switch for BIM, rising costs, problems in responsibility of drawing as well as mentioning that improvements and standards are needed in e related systematic improvements. In addition, Jun Gi Hyun and the rest (2011) pointed out the problems related to the lack of professionals, low efficiency compared to the costs, and adhesion of existing methods.

Including the major information included above, the problems that are identified as problems are the lack of task process for BIM standards, standardization of information technology and resources, appropriate BIM ordering instructions including comprehension about the employer, price realization following the increase in costs, construction of library, difficulties in collaboration, contractor following the problems of ordering methods, absence of the subcontractors of the construction, problems in the evaluation method of completed BIM, classifycation system and absence of data format, absence of certification system, interface problems that require all the data that is needed in the analysis during the design phase, as well as explanation over various problems. The fact that these problems are being describe can be understood that the BIM application and research are actively conducted.

\section{Analysis of Changes in Perception of CIvil Engineering Companies}

This research analyzed 3 criteria out of 90 survey criteria and researched on what kind of changes occurred in the BIM market during the last 2 years. These were the changes in interest regarding BIM, transformation of restraints, and changes based on factors. This survey was conducted on 20 of the top 50 civil engineering companies.

\section{Changes in Interets about BIM}

During the last couple of years, BIM has been greatest inter- est for construction companies, so diverse efforts have been displayed in order to apply it onto practices of construction companies. According to research results, regardless of experience in application of BIM, the response to recognition of BIM was $83.2 \%$, which is $5 \%$ greater compared to the results in 2010. Also, regarding the BIM interest report, the percentage increased from $93.5 \%$ to $96 \%$. These results display that sufficient base expansion occurred for BIM technology (Figure 1).

\section{Changes in Restraints Regarding Introduction of BIM}

According to the survey (2009) results regarding restraints of BIM application that was conducted in the United States, lack of education and BIM professionals, BIM introduction expenses, lack of will to introduce BIM, and lack of costs have been considered as restraints that hinder activation of BIM. In terms of restraints in Korea as reported through the 2010 Korean Construction Technology Research Center, lack of information and education, lack of standard and guidelines, lack of operators, lack of will of the executive officer, and absence of successful cases in practical application, and confusion and absence of government policy have been displayed in order.

Even in 2012 reports, restraints have been analyzed as being similar. When 2 unique traits within the reported information are analyzed, the reason why the number of no-requests from users has increased in contrast to 2010 is because the base has been expanded but due to the slowdown in the construction, the ordered amount was not satisfactory. Thus, it was considered that the cause could be found, and the fact that $\mathrm{H} / \mathrm{W}, \mathrm{S} / \mathrm{W}$ has high costs is being displayed as an constant problem.

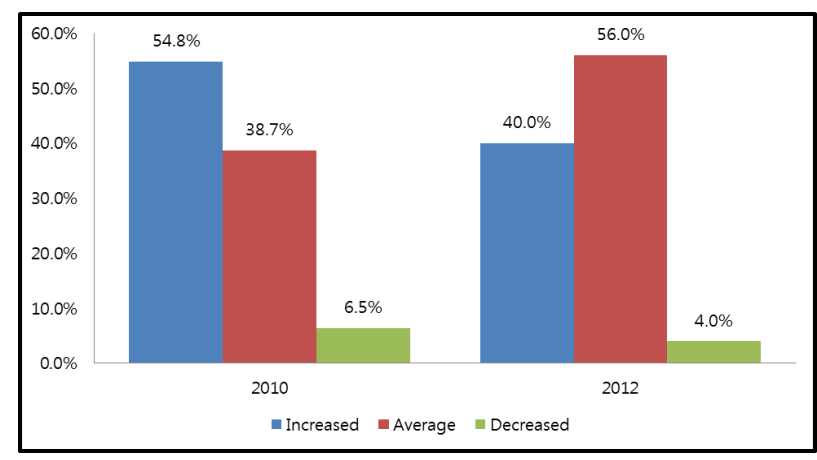

Figure 1.

Interests about BIM.

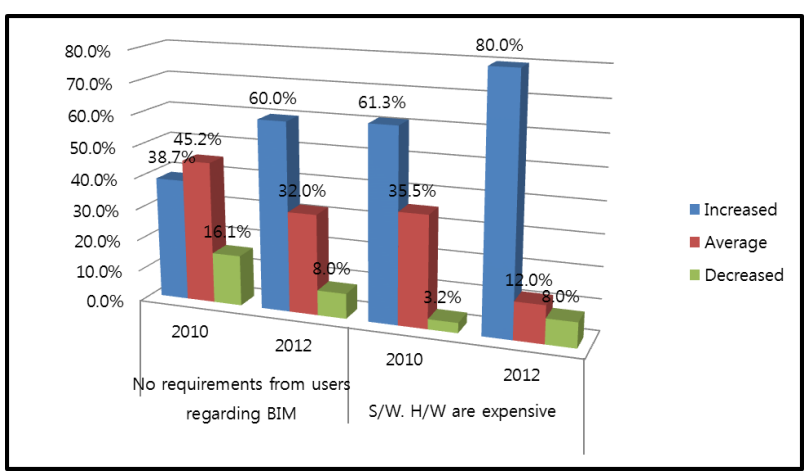

Figure 2.

Restraits to Introduction of BIM. 


\section{Changes in Needs Needed for Introduction of BIM}

In the needs survey regarding the problems have to be predetermined in order for BIM to become activated in Korean civil engineering field, the restraints of the will of the executive officer and decision-makers, technological support of solution, applied technology and standards have been reported as significantly decelerated, but areas such as the absence of government policy, economical efficiency in case of practical application of BIM still remain as insufficient and are being questioned (Figure 3).

\section{Classification of Problems and IMprovement}

When problems listed on chapter II, III, IV are combined, they can be classified into different problems such as problems on task process needed for application of BIM, lack of collaboration system and mind, lack of library, absence of standards, and absence of professionals. When each of the problems are divided, they can be divided into 3 kinds such as Improvements in project implementation, Improvements in Information Infra, and Improvement of system.

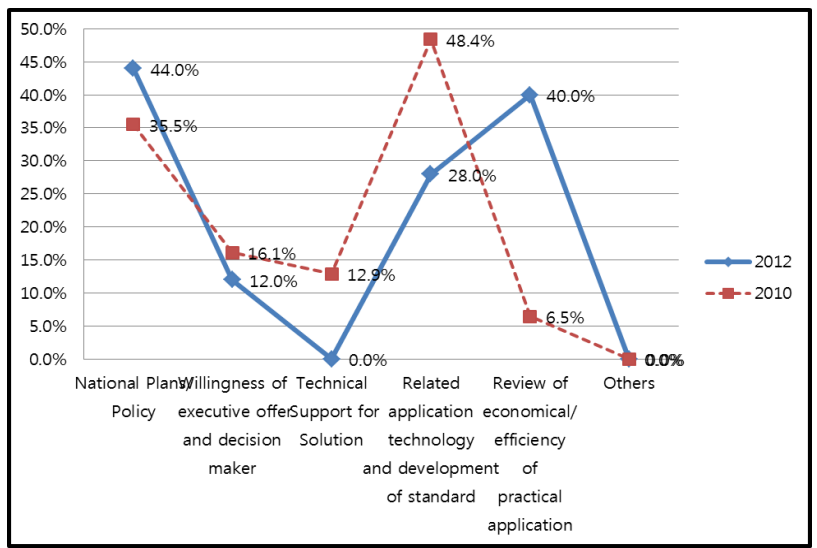

Figure 3.

Needs that are required for introduction of BIM.

Table 2.

Classification of Problems and Improvement.

\begin{tabular}{ll}
\hline Problems & Area \\
\hline $\begin{array}{l}\text { - Lack of Support System in Task Process needed for } \\
\text { application of BIM }\end{array}$ & Area of Project \\
- Lack in Workability in the design model & Implementation \\
- Lack in the will of making changes happen & Procedures \\
- Lack in Collaboration System and Collaboration & \\
Mind & \\
& \\
- Lack of Library & \\
- Lack of Compatible Data & \\
- Lack of Standard Guidelines & \\
- Lack in Functions of the Software & \\
- Lack of Object Classification & \\
- Lack of Recycled Information & \\
& \\
- Lack of Professionals & \\
- Lack of National Policies & \\
- Existence of Intellectual Property Rights such as \\
data and drawings \\
- Lack of Ordering Method and evaluation/verification \\
system of BIM data
\end{tabular}

\section{Improvement in Terms of Project Implementation Process}

In the design where BIM is applied, the task process change from 2D design to 3D design has to be accompanied. However, currently, in the transition stage, costs have been rising and problems have been rising for collaboration system during the stage where 2D design is changed into 3D. Regarding the problems of the process, adequate reconstruction of project conducting process regarding BIM design or through the IPD (Integrated Project Delivery), introduction of overall ordering method, maximized process that consider changes in construction tasks and transformation of groups have to be searched. In addition, in terms of strategies of the nation, plans that consider the changes in the process have to be provided.

\section{Improvement in the Area of Information Infra}

Problems such as development of standard and guidelines, secure of data compatibility, and secure of library can be considered as problems that are relevant to base infra needed for the application of BIM. IFC standards and international standards are basically applied, but parts that have to be fixed to fit the domestic environment have to be researched first in order to prevent expansion and confusion of BIM base. In terms of improvement on infra, procedural improvement on development of standard guidelines and expansion of various standards are needed.

\section{Improvements on the System}

Improvements on ordering methods, provision of evaluation system, authentication system, education system, and advertisement which have to be improved in terms of systems are parts that have to be strategically approached by the government. All content in the system directly influence on the Industry, cooperational system with the organization and applications on diverse committee as well as other considerate approaches are needed.

\section{Conclusion}

In the current domestic situation as recognition and application of BIM is expanding, this research has expressed the possibility of solving everything and diagnosed the problems regarding BIM. Also, research was process in order to verify these problems.

In addition, during the past 2 years, changes in awareness of issue were analyzed and by dividing the problems, the need of strategic approach was suggested. In order to solve these problems, improvement of performed procedures of the project, infra aspects, and system aspect have to be applied for complementary research and support has to be accompanied.

\section{Acknowledgment}

This research was implemented as a part of the important business (12 major-commission) Infra BIM information model standard and development of verification technology) of Korean Construction Technology Research Center.

\section{REFERENCES}

K. H Jun, S. H Yun”Developing Construction Object Library for BIM 
K. B. JU, M. B. SEO

Based Building Construction Planning” Architectural Institute of Korea, vol 275, pp 143-151 2011

J.C Seo, I.H Kim, “A Study on the Basic Directions for Introducing and Applying Building Information Modeling inf the Public Construction Project Delivery” Architectural Institute of Korea, vol 251, pp 21-30 2009

McGraw Hill Construction, BIM SmartMarket_Report 2008, 2009
Weise M., Liebich T., Tulke J. \& Bonsma P., "Disscussion paper: IFC support for model-based scheduling", Public specification of the NMP-EU project InPro (IP 026716-2), March 2009, available at: www.inpro-project.eu

buildingSmart Internatioal Model Support Group website, http://www.buildingsmart-tech.org/specifications/ifc-releases/ifc2x4release/rc3-release/rc3-release-summary 